DOI:10.17951/h.2016.50.3.29

\begin{tabular}{lcc}
\hline \multicolumn{3}{c}{ A N N A L E S } \\
UNIVERSITATIS MARIAE CURIE-SKŁODOWSKA \\
LUBLIN - POLONIA \\
VOL. L, 3 & SECTIOH H \\
\hline
\end{tabular}

Gdańsk University of Technology. Faculty of Management and Economics

PIOTR SYLWESTER GIRUĆ

Piotr.Giruc@zie.pg.gda.pl

\title{
Derivative Instruments Dedicated for Agricultural Commodity Entities in Poland
}

Instrumenty pochodne stosowane na rynku rolnym w Polsce

Keywords: agricultural commodities; derivatives; hedging

Słowa kluczowe: produkty rolne; instrumenty pochodne; zarządzanie ryzykiem w rolnictwie

JEL Code: G1; G13; G15

\section{Introduction}

The aim of this paper is to determine how agricultural derivative instruments could affect trading companies' economic decisions in Poland.

There are three different types of companies in the market and three differentiated approaches to economic existence but relying on the same demand and supply market mechanism. Importers, producers and trading companies are participating in the supply and demand continuous game that by output generates fluctuation of the price. Once gives a profitable and prosperous season if forecasted correctly, another time due to disadvantageous trend of price, their activity may be driven to the bankruptcy in the very near future. For most of them, cash market operations are only means of securing transactions, however, it limits overall trading to spot or maximum quarterly contracts. Here, hedging is restricted to specifying price of product.

For the companies and producers well developed and aware and socially responsible in terms of business contract, it is a binding agreement to fulfill the terms, 
for others it is not that ethically obvious and honestly approved. When taking under consideration that there are over 5,000 premises and approximately 200 feed factories with trading companies in Poland, one could assume low probability of purchasing the product and later on retrieving it.

\section{Bases on agricultural derivatives in Poland}

Derivatives on Polish agricultural market are present broadly since 2002, however initial indexation and presence on GPW was in 1999 [Ustawa z dnia 26 października 2000 r. o giełdach towarowych]. No matter the dates, however, they were input into financial system quite recently. From this point, general conclusion is that the knowledge of mechanisms driving the system is insignificant. Amongst CFO's, there is a conviction of great deal of risk exposure when utilizing them. Such outcome is a result of weak orientation on forward markets and missing completely the truth of derivative instruments. The truth is that they are exclusive instruments of minimizing the risk. Nevertheless, the effective utilization is strictly connected with manager's portion of adequate knowledge and experience. Therefore, essential solution leads to increase of knowledge describing advantages of derivative instruments for companies with various exposure to risk.

Price fluctuation seems to be crucial difficulty to manage for the both sides of agricultural contract. It is not a problem to actually get contracted product when, for instance, trading company or a mill contracted wheat as much as they could at the price of PLN 900 and in the future prices declined to PLN 500 - the producer will push with deliveries and almost certainly with use contracted $+5 \%$ of contracted amount. On the contrary, when PLN 900 contracted becomes lower from the present market value for about PLN 100-200, there could be a doubly chance to have your wheat delivered. Farmers or producers are ready to do anything to jump out of the contract, i.e. to subtract $-5 \%$ of signed amount, to pay any sanctions if a buyer sets up a trial. Such practices were exercised in years when prices of agriculture goods rallied up - colloquially called "default years". By a default we understand that one of the parties did not accomplish their part and it became most probable that the resolution would end up in court. This sanction, the value of which is usually set for $10 \%$ of contract value, is still less expensive than the loss caused by the changes in price on the market. Thus, some sellers, by quick reevaluation of profit and loss, decide to break an agreement.

Having the honest counterpart found and verified, cash market can offer some more for the buyers and sellers. One flat price for new crop of harvest or even old one but with significantly delayed deliveries is great mean to hedge the price level of contracted goods. For all agreements of unsure traders, a new idea of the price was introduced - prices based on formulas. Formulas are negotiable to some extent. However, base is frequently the same - base of the price for agricultural products 
are Matiff and CBOT future contracts, choosen adequately to delivery dates. This solution divides the risk between the both sides of contract, nevertheless, none part is secured from price fluctuations - the flat price is much better obviously, but facilitates uncertainty of deliveries. New crop harvest formulas tend to be calculated a few Euros or Dollars below the selected contract. However, this year, due to harsh and prolonged cold weather, new crop is quoted even higher than old one (above the Matiff contract up to EUR 10).

Neither the flat price, nor formula prices follow exactly the prices in all countries. In contradiction to currencies where all values are consistent amongst the brokers, banks and market makers, in commodity market, each country can have different formula price according to Matiff or CBOT quotations. Supply and demand situation in various countries is different, thus import and export of goods from one to another country is leading to variations of prices. The more demand a country shows for wheat, it is paying/quoting higher that countries that have enough of the product [Dorsey et al., 2007, p. 154]. Each year such situations are vivid. For instance, last year Germany started quoting new crop higher than neighbor countries by 10 Euros (Matiff +8 Euros) after report of new crop in Germany stated less new crop than was awaited. Much of wheat from Poland was exported in new crop months, from July to October, and after another quarter was retrieved by Polish companies back to Poland. During the import to Poland, prices in Poland were higher by 7 Euros (Matiff +6 Euros).

These companies that bought future crop on formula should carefully analyze market situation and try to forecast whether their country is going to be an exporter or importer in the season [Dunsby et al., 2008, p. 109]. When they bought the goods with formula below the Matiff and their country appeared to be an importer, they would have a free margin from the sale of goods, otherwise if the country was exporting more goods to others, they would suffer a loss. Commonly the fluctuation of the nation price to Matiff is called premium. Premiums on agricultural goods are moving from -70 Euros to +70 Euros depending on the good and the year.

When cash market is limited with the opportunities, other solutions may be of better value. Nowadays, financial markets are trying to raise and bear the risk within its instruments on the commodity market. The situation described by an agricultural business entity is to present tendencies and trends in financial risk-securing methods. It allows to observe how derivative instruments evolve and satisfy hedging needs.

\section{Incorporation of derivative instruments in grain trading company}

Processing and grain trading enterprise Ziarnpol Ltd. is present on Polish market since 1998. Ziarnpol Ltd. had an idea to start securing their stock price and contracts leading into the future. The company had no knowledge and experience in putting the idea into the practice, therefore, what they could do, was to sign some 
forward contracts as some proper method of securing their risk. In case of rapeseed grains, volume of hedged good constituted around $40-50 \%$ of purchased and later on traded goods.

In order to keep positions on the right side of market, constant reevaluation of net position is required. Some contracts will demand long positions, other short, and it is not permitted by common sense to keep two opposite positions, therefore they are summed to absolute value. Based on selection of goods with higher and lower premium value to the exchange trading of goods will have to eliminate positive premium so as to prevent from minor place for loose. All hedging will depend on derivatives, one kind or their combination according to demands of the situation [Frost, 1994, p. 30].

Currencies may be secured either in bank or on exchange that offers interesting currency cross pair. For Polish companies that operate originally in PLN, each pair is most volatile in banks which are standing as market makers. For Ziarnpol Ltd., it is recommended trading in EUR/PLN on e-WGT Exchange in Warsaw that offers interesting derivatives - future and options, additionally involving less operational costs.

Commodity derivatives are not present in Poland. The closest volatile exchange is EURONEXT Paris (Matiff), reachable in one of London's brokers. First hedging is required for deposit which usually is in foreign currency and must fill in initial margin required for opening contracts and later variable margin to hold position in case of negative evaluation of the position. For an example of hedging, there is a typical transaction of purchasing and selling wheat for Ziarnpol Ltd. Presented method will include a mix of all accessible derivative instruments, required deposits and a total cost of operation.

Ziarnpol Ltd. sold a global amount of 12,000 tons of wheat that will be delivered each month by 1,000 tons to another Polish company. The price granted is PLN 862 for the whole period. As Ziarnpol Ltd. does not possess that amount of wheat at the time, risk of retrieving wheat for higher price is moderately probable. Quick calculation of crediting and storing wheat in Ziarnpol Ltd. bins shows that monthly such operations in total give PLN 10 per ton. With today's price of PLN 852 for such product, after 11 month with crediting and storing costs, the final price would be PLN 962. Such end price is by PLN 100 too high for contracted price, even mean value is PLN 907, and this is still PLN 45 too high. Multiplying 12,000 tons by PLN brings PLN 10,880,000.00 whereas contracted total value equals PLN 10,344,000. The difference is PLN 536,000. This might be the loss for Ziarnpol Ltd. if they hadn't the chance to purchase 12,000 tons of wheat in the first month of signed agreement.

Table 1 presented the data described above. What is most interesting, the initial price for Ziarnpol Ltd. to start with purchases on terms of storing and crediting the stock is PLN 852. This price is (PLN 907-862) PLN 45 below present market price level for wheat. 
Pobrane z czasopisma Annales H - Oeconomia http://oeconomia.annales.umcs.pl

Data: 26/04/2023 07:48:49

DERIVATIVE INSTRUMENTS DEDICATED FOR AGRICULTURAL COMMODITY ENTITIES IN POLAND

Table 1a. Contract value calculations

\begin{tabular}{|l|c|c|c|c|c|c|}
\hline \multicolumn{1}{|c|}{ Months } & I & II & III & IV & V & VI \\
\hline Wheat needed & 1,000 & 1,000 & 1,000 & 1,000 & 1,000 & 1,000 \\
\hline Wheat price calculated [PLN] & 892 & 902 & 912 & 922 & 932 & 942 \\
\hline Wheat quantity contracted & 0 & 0 & 0 & 0 & 0 & 0 \\
\hline $\begin{array}{l}\text { Wheat price contracted } \\
{[\text { PLN] }}\end{array}$ & 862 & 862 & 862 & 862 & 862 & 862 \\
\hline Wheat hedged - Matif & 0 & 0 & 0 & 0 & 0 & 0 \\
\hline Price hedged - Matif & - & - & - & - & - & - \\
\hline$€ /$ PLN & - & - & - & - & - & - \\
\hline $\begin{array}{l}\text { Difference between price contracted } \\
\text { and stored [PLN] }\end{array}$ & 30 & 40 & 50 & 60 & 70 & 80 \\
\hline P/L on price difference total-thousand & -30 & -40 & -50 & -60 & -70 & -80 \\
\hline Short/long & $-1,000$ & $-1,000$ & $-1,000$ & $-1,000$ & $-1,000$ & $-1,000$ \\
\hline
\end{tabular}

Source: own study.

Table 1b. Contract value calculations

\begin{tabular}{|l|c|c|c|c|c|c|c|}
\hline \multicolumn{1}{|c|}{ Months } & VII & VIII & IX & X & XI & XII & $\Sigma$ \\
\hline Wheat needed & 1,000 & 1,000 & 1,000 & 1,000 & 1,000 & 1,000 & 12,000 \\
\hline Wheat price calculated [PLN] & 952 & 962 & 852 & 862 & 872 & 882 & 907 \\
\hline Wheat quantity contracted & 0 & 0 & 1,000 & 0 & 0 & 0 & 1,000 \\
\hline Wheat price contracted [PLN] & 862 & 862 & 862 & 862 & 862 & 862 & 862 \\
\hline Wheat hedged - Matif & 0 & 0 & 0 & 0 & 0 & 0 & 0 \\
\hline Price hedged - Matif & - & - & - & - & - & - & - \\
\hline$€ /$ PLN & - & - & - & - & - & - & - \\
\hline $\begin{array}{l}\text { Difference between price } \\
\text { contracted and stored [PLN] }\end{array}$ & 90 & 100 & -10 & 0 & 10 & 20 & 45 \\
\hline $\begin{array}{l}\text { P/L on price difference } \\
\text { total-thousand }\end{array}$ & -90 & -100 & 10 & 0 & -10 & -20 & -540 \\
\hline Short/long & $-1,000$ & $-1,000$ & 0 & $-1,000$ & $-1,000$ & $-1,000$ & $-11,000$ \\
\hline
\end{tabular}

Source: own study.

Concluding, one shall offer price of PLN 907 for annual deliveries, but it may be not be attractive for the buyer who possibly would check other offers under 900 PLN level.

With hedging, one calculates initially demand for the deposit depending on the strategy [Rogers, 2004, p. 72]. On commodities for quick execution, one is going to open positions with future contracts. One contract on Matiff is 50 tons of wheat. Deposit for one contract is EUR 1,400, which constitutes EUR 28 per ton. Ziarnpol Ltd. at the moment of signing the agreement, observed wheat at average price on EUR 198 what on present EUR/PLN exchange rate of 4.30 gives PLN 851.4. Deposit poses $15 \%$ of 50 ton contract exposition value. For total amount to be hedged, it is needed to buy 240 contracts, 20 per month. Global deposit for all contracts requires EUR 336,000 or over PLN 1,000,000. Such amount, if not taken from the company, obviously will be lent from bank that would offer buyers credit on $6.25 \%$ interest rate. Bank's interest rates entirely will cost company PLN 7,700 after one year or PLN 0.06 per ton of wheat, which is a pretty low price for security. 
The last expenditure as for having hedged positions appears broker's commission to open and close position. Varying cost depending on broker, amount of contracts traded per months and exchange, it can be 3 USD per side per contract what in round turn gives USD 6 or EUR 4.25 for both opening and closing position. Per ton round turn oscillates between PLN 0.70 and 0.80 . Supposing it is 0.78 PLN at the moment, it would finally equal PLN 9,181. Table 2 visualizes how much is added to the price from the original one traded on the exchange. Usually values are minor to the final offer what is facilitating hedging.

Table 2. Setting up position on Matiff and calculation of hedging operational costs (Volume 1000 monthly, $€ /$ PLN rate 4.3000 , Number of contracts 20 monthly)

\begin{tabular}{|c|c|c|c|c|c|c|c|c|c|}
\hline Months & $\begin{array}{c}\text { Dep. MIR } \\
{[\text { in } 1000 €]}\end{array}$ & $\begin{array}{c}\text { Round } \\
\text { turn } \\
{[\text { in } €]}\end{array}$ & $\begin{array}{c}\text { Value of } \\
\text { position } \\
{[\text { in 1000 } €]}\end{array}$ & $\begin{array}{c}\text { Dep. } \\
\text { Cost } \\
{[\text { in } €]}\end{array}$ & $\begin{array}{c}\text { Dep. } \\
\text { cost/t } \\
{[\text { in } €]}\end{array}$ & $\begin{array}{c}\text { Round/t } \\
{[\text { in } €]}\end{array}$ & $\begin{array}{c}\text { Matiff } \\
{[\text { in PLN] }}\end{array}$ & $\begin{array}{c}\text { Price } \\
{[\text { in } €]}\end{array}$ & $\begin{array}{c}\text { Price } \\
{[\text { in PLN] }}\end{array}$ \\
\hline I & 28 & 174.55 & 336 & 0.01 & 0.18 & 196 & 851.40 & 196.25 & 852.48 \\
\hline II & 28 & 174.55 & 308 & 0.01 & 0.18 & 196 & 851.40 & 196.25 & 852.48 \\
\hline III & 28 & 174.55 & 280 & 0.01 & 0.18 & 196 & 851.40 & 196.25 & 852.48 \\
\hline IV & 28 & 174.55 & 252 & 0.01 & 0.18 & 196 & 851.40 & 196.25 & 852.48 \\
\hline V & 28 & 174.55 & 224 & 0.01 & 0.18 & 196 & 851.40 & 196.25 & 852.48 \\
\hline VI & 28 & 174.55 & 196 & 0.01 & 0.18 & 196 & 851.40 & 196.25 & 852.48 \\
\hline VII & 28 & 174.55 & 168 & 0.01 & 0.18 & 196 & 851.40 & 196.25 & 852.48 \\
\hline VIII & 28 & 174.55 & 140 & 0.01 & 0.18 & 196 & 851.40 & 196.25 & 852.48 \\
\hline IX & 28 & 174.55 & 112 & 0.01 & 0.18 & 196 & 851.40 & 196.25 & 852.48 \\
\hline X & 28 & 174.55 & 84 & 0.01 & 0.18 & 196 & 851.40 & 196.25 & 852.48 \\
\hline XI & 28 & 174.55 & 56 & 0.01 & 0.18 & 196 & 851.40 & 196.25 & 852.48 \\
\hline XII & 28 & 174.55 & 28 & 0.01 & 0.18 & 196 & 851.40 & 196.25 & 852.48 \\
\hline$\Sigma$ & 336 & 2094.55 & - & 0.01 & 0.18 & 196 & 851.40 & 196.25 & 852.48 \\
\hline
\end{tabular}

Source: own study.

Final price that can be hedged by placing orders on Matiff is EUR 196.25 and with secured currency exchange rate of EUR to PLN gives us ultimate price of PLN 853, extra nearly PLN 9 per ton of margin for Ziarnpol Ltd.

\section{Comparison of non-hedged and hedged with derivative instruments applied by Ziarnpol Ltd.}

Contract signed by Ziarnpol Ltd. is one of many that can lead company to bankruptcy or prosperity. Without hedging, outcome is only the streak of luck. Hedging is limiting the hazard of bankruptcy and if properly introduced, can increase the margin.

Contracted 12,000 tons of milling wheat with mean value of PLN 862 is PLN 45 from the value that can be realistically found in the market. Willing to buy entire amount in one month is quite a challenge due to export that usually appears in harvest time in Poland. Such situation pushes the price up what brings vague assumption 
whether contracted price can be met. Nonetheless, if all wheat is bought in one month PLN 907 is real mean value for annual contract.

The table 3 vividly shows how finances of contract behave when market change it price. It is limited to one exchange rate value of EUR/PLN. As mentioned before the change by 0,0100 of currency varies contracted value by 23520 PLN.

Table 3. No hedging versus hedging. Net value of positions

\begin{tabular}{|c|c|c|c|c|c|c|}
\hline & \multicolumn{2}{|c|}{ Input price } & \multicolumn{4}{|c|}{ Matiff price } \\
\hline & Value & $€ 196$ & $€ 203$ & $€ 215$ & $€ 180$ & $€ 176$ \\
\hline$€ /$ PLN & 4.3 PLN & 842.80 PLN & 872.90 PLN & 924.50 PLN & 774 PLN & 756.8 PLN \\
\hline \multicolumn{7}{|c|}{ SCENARIO I [THOUSAND PLN] } \\
\hline $\begin{array}{l}\text { No hedging } \\
\text { contracted }\end{array}$ & 12 & $10,113.6$ & $10,474.8$ & 11,094 & 9,288 & $9,081.6$ \\
\hline Price & 0.862 & 10,344 & 10,344 & 10,344 & 10,344 & 10,344 \\
\hline Balance physical & 12 & $10,113.6$ & $10,474.8$ & 11,094 & 9,288 & $9,081.6$ \\
\hline Balance financial & 12 & - & - & - & - & - \\
\hline Net value & - & 23.04 & -130.8 & -750 & 1,056 & $1,262.4$ \\
\hline \multicolumn{7}{|c|}{ SCENARIO II [ THOUSAND PLN] } \\
\hline Hedging contracted & 12 & $10,113.6$ & $10,474.8$ & 11,094 & 9,288 & $9,081.6$ \\
\hline Price & 0.862 & 10,344 & 10,344 & 10,344 & 10,344 & 10,344 \\
\hline Balance Physical & 12 & $10,113.6$ & $10,474.8$ & 11,094 & 9,288 & $9,081.6$ \\
\hline Balance financial & 12 & - & 130.8 & 750 & $-1,056$ & $-1,262.4$ \\
\hline Net value & - & 230,4 & - & - & - & - \\
\hline
\end{tabular}

Source: own study.

One Euro of Matiff price difference costs Ziarnpol Ltd. potentially PLN 51,600. This is the exposure that company takes on their shoulder if they are not securing themselves in this contract.

There is no doubt of the fact that hedging is essential for well-being of company's stable financial condition. Ziarnpol Ltd. being at the very beginning of this venue tried some market tools in order to try how it works. None of serious big scale undergoing was triggered so far. Show cased calculations for president were quite a surprise how derivatives and currencies can influence the final result. The company was aware of the extent of loss or profit but lived in assumption that taking and managing positions on the exchange, increases much of effort and another costs. Calculations proved it wrong and have opened thinking for new way of ruling the business. With hedging and more importantly combination of currency and commodity positioning, company can function effortlessly and eventually gain some extra income from measured thinking. 


\section{Conclusions}

Case study accounted in Ziarnpol Ltd. has showed real life situation and presented how calculations that are actually introduced. Based on the evaluation, company can try to select the instrument most suitable for the assignment and compare it to non-hedged situation which does not look well when market is opposite to presumed scenario. Future and options are cited and their parameters were adduced along with their outcome. In this sole example, risk was limited nearly entirely, the minimal slippage on EUR/PLN exchange by 2 Grosz is the only minor risk, though risk is in total minimized by over $90 \%$ in comparison to the potential loss from not securing at all.

As mentioned, comprising transactions on derivative market in Poland is observed as relatively very risky. The key reasons are media that are apt to confirm myth every time there is a drastic change on financial markets that utilized derivative instruments. Nonetheless, reality is quite the opposite; approved reason is faulty, inappropriate and unskillful application of securities with overrated speculations with derivatives. Alternatively, problematic may be the lack of control of transaction administrators; as an instance of Barrings Bank's employee that solely led to bankruptcy after a series of faulty transactions [Winiecki, 2010].

Having the view of Polish commodity markets and lack of financial knowledge of managers, one can conclude that most business entities and within even more agricultural producers are mostly unprepared and unaware of derivative instrument. But still developing financial consciousness of derivative market among CFOs bodes positively for the future.

Results are very promising and boding secured future for company. So far, contract is being realized, margin is kept constant and appetite of company's representative for other solutions opened.

\section{Bibliography}

Dorsey T.J., DeRosier T.F., Keeton P.L., Morrison S.L., Commodity Strategies. High-Profit Techniques for Investors \& Traders, John Wiley \& Sons, New Jersey 2007.

Dunsby A., Eckstein J., Gaspar J., Mulholland S., Commodity Investing. Maximum Returns through Fundamental Analysis, John Wiley \& Sons, New Jersey 2008.

Frost R.J., Options on Futures. A Hands-On Workbook of Real-World Trading Simulations and Money-Making Strategies, Probus Publishing Company, Chicago 1994.

Rogers J., Hot Commodities. How Anyone Can Invest Profitability in the World's Best Market, Random House, New York 2004.

Ustawa z dnia 26 października 2000 r. o giełdach towarowych (Dz.U. z 2000 r., nr 103, poz. 1099; opracowano na podstawie: t.j. Dz. U. z 2005 r., nr 121, poz. 1019, nr 183, poz. 1537 i 1538, Dz.U. z 2006 r., nr 157, poz. 1119, Dz.U. z 2007 r., nr 112, poz. 769, Dz.U. z 2008 r., nr 171, poz. 1056, Dz.U. z 2009 r., nr 165, poz. 1316, nr 168, poz. 1323, nr 201, poz. 1540, Dz.U. z 2010 r., nr 21, poz. 104).

Winiecki S., Bariery rozwoju instrumentów pochodnych w Polsce, 2010, www.winiecki.com.pl/2010/01/ bariery-rozwoju-instrumentow-pochodnych-w-polsce [access: 12.05.2011]. 


\section{Instrumenty pochodne stosowane na rynku rolnym w Polsce}

Celem badań, których wyniki zostały przedstawione w pracy, było określenie, jaki wpływ mają zastosowane instrumenty pochodne na wyniki finansowe przedsiębiorstwa handlowego w obrocie zbożem. Artykuł składa się z dwóch części. W pierwszej przybliżono zagadnienia dotyczące wykorzystania instrumentów pochodnych na rynku rolnym w Polsce. Druga część zawiera wyniki badań dotyczących możliwości wykorzystania zabezpieczenia ceny transakcji w handlu zbożem.

\section{Derivative Instruments Dedicated for Agriculture Commodity Entities in Poland}

The aim of the research, the results of which are presented in this paper, was to determine how agricultural derivatives imply financial results of the company dealing with wheat trading. The article consists of two parts. The first one presents possibility for applying agricultural derivatives in Poland. The second part contains the results of the research demonstrating the impact of agricultural derivatives on price hedging in the course of wheat trading based on chosen company. 